Want to become a Thieme author?

Find great resources for journal authors here.
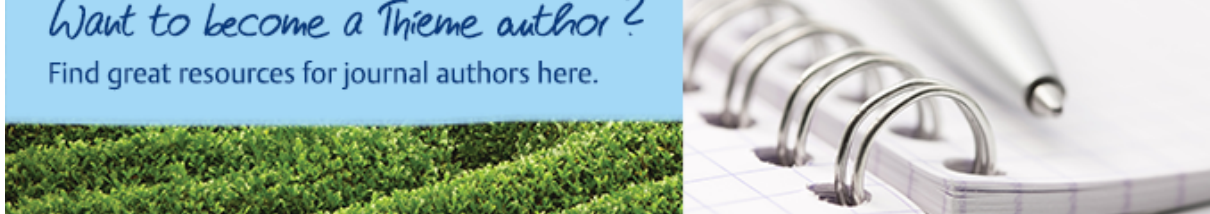

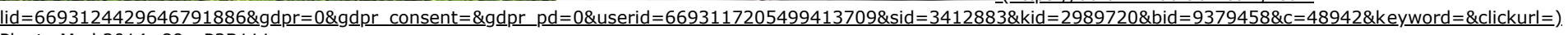
Planta Med 2014; 80 - P2B111

DOI: $10.1055 / \mathrm{s}-0034-1394988$

\title{
In vitro anti-cancer activities of Poiretia bahiana and Acritopappus confertus
}

C Pinho $\underline{\mathbf{1}}, \underline{\mathbf{2}}$, A Oliveira $\underline{\mathbf{1}}, \underline{\mathbf{2}}$, A Carvalho $\underline{\mathbf{1}}$, C Lima $\underline{\mathbf{1}}$, A Dias $\underline{\mathbf{1}}$

${ }^{1}$ Centre for the Research and Technology of Agro-Environment and Biological Sciences (CITAB-UM), AgroBioPlant Group, Department of Biology, University of Minho, Portugal

${ }^{2}$ Nucleo de Investigação e Informação em Farmácia (NIF), Centro de Investigação em Saúde e Ambiente (CISA), Escola Superior de Tecnologia de Saúde do Porto - Instituto Politécnico do Porto (ESTSP-IPP), Vila Nova de Gaia, Portugal

Congress Abstract

Cancer is one of the greatest killers worldwide and is spreading promptly. Increasing interest and research on herbal medicine have revealed its importance in treating many diseases, including cancer. This study aims to evaluate the anticancer properties of the Poiretia bahiana and Acritopappus confertus, plants widely used in Bahia (Brazil) folk medicine, against a panel of four human cancer cell lines representing different tissues (liver, breast, colon and neuroblastoma). Aqueous ethanolic $(80 \%)$ extracts were prepared from aerial parts of those plants, concentrated and dissolved in DMSO at desired concentrations. Cancer cells lines at proliferative phases were treated with the plant extracts and incubated for $48 \mathrm{~h}$ at $37^{\circ} \mathrm{C}$ and $5 \%$ carbon dioxide $\left(\mathrm{CO}_{2}\right)$. In vitro cytotoxicity was determined by 3-(4,5-dimethythiazol-2-yl)-2,5-diphenyl tetrazolium bromide (MTT) assay and percent inhibition of growth of the cells was calculated. The results showed decreased cell viability in a concentration dependent manner, demonstrating that aqueous ethanolic extracts of $P$. bahiana and $A$. confertus have a potential cytotoxicity activity on T47D (breast), SH-SY5Y (neuroblastome) and HCT116 (colon) cell lines and were not so effective on HepG2 (liver). The best anticancer activity was observed for extract of $P$. bahiana on HCT116 cell line with an $\mathrm{IC}_{50}$ of $0.5 \mu \mathrm{g} / \mathrm{mL}$. Aqueous ethanolic extract of $A$. confertus also showed good activity with an IC 50 of 4.6 $\mu \mathrm{g} / \mathrm{mL}$ and $9.3 \mu \mathrm{g} / \mathrm{mL}$ for SH-SY5Y and T47D cell lines, respectively. Further studies are required regarding the isolation and characterization of bioactive components along with the analysis of molecular mechanism involved.

Acknowledgemens: This work was supported by Fundação para a Ciência e Tecnologia (FCT), projects PTDC/AGRALI/105169/2008 and PEst-OE/AGR/UI4033/2014.

Keywords: Poiretia bahiana, Acritopappus confertus, anti-cancer activity 